\title{
IMPROVING PUBLIC MANAGEMENT AS ONE OF THE WAYS OF REFORM FOR SUSTAINABLE DEVELOPMENT
}

\section{УДОСКОНАЛЕННЯ ПУБЛІЧНОГО УПРАВЛІННЯ ЯК ОДИН ІЗ НАПРЯМІВ РЕФОРМУВАННЯ В ЗАБЕЗПЕЧЕННІ СТАЛОГО РОЗВИТКУ}

The national system of state power is characterized by rather complex and contradictory processes aimed at a radical reform of the cumbersome and inefficient system of public administration. The system needs radical modernization that would enable a reliable and efficient modern system of public administration. The article analyzes the experience of reforming the sphere of public administration, outlines the prospects for improving public administration in ensuring sustainable development. The process of public administration reform is presented as a transition from traditional values to modern, effective management systems that can easily adapt to a constantly changing external environment. As a result of administrative reform comes the principle of autonomy of responsibility for the execution of the main mission assigned to state structures. Therefore, organizational flexibility, innovation management, decentralization, staff freedom of action should be addressed in the foreground. It was stated that innovative social technologies of improvement of public management are a mechanism for combining experience and knowledge, described by operations and stages, with the conditions of their implementation in modern management practice. The main priorities of the functioning of government bodies are meeting the needs of consumers, providing them with high-quality and timely services, building confidence in the government. Promising areas for improving public governance in sustainable development should be: developing a flexible, stable and efficient management system; professionalization of the civil service; implementation of the principles of decentralization of the state administration system, service administration, corporatism and neo-corporatism, etc. The introduction of effective mechanisms for reforming public administration will contribute to the successful fulfillment of Ukraine's strategic development goals.

Key words: public administration, reform, improvement of public administration, sustainable development.

Національна система державної влади характеризуються досить складними i суперечливими процесами, спрямованими на докорінне реформування громіздкої і неефоктивної системи державного управління. Система потребує докорінної модернізації, що дало б можливість створити надійну та ефрективну сучасну систему державного управління. У статmі проаналізовано досвід реформування сфрери публічного управління, окреслено перспективи вдосконалення державного управління в забезпеченні сталого розвитку. Прочес реформування публічного управління представляємо як перехід від традиційних иінностей до новітніх, есрективних систем управління, що можуть легко адаптуватися до постійно змінного зовнішнього середовища. у результаті адміністративної ресрорми виникає принчип автономії відповідальності за виконання основної місії, покладеної на державні структури. Тому перш за все необхідно звернути увагу на організаційну гнучкість, управління інноваціями, децентралізацію, свободу дій персоналу. Констатовано, що інноваційн соціальні технолосії вдосконалення публічного управління представляють собою розписаний за операціями й етапами механізм поєднання досвіду і знань з умовами їх реалізації в сучасній практиці управління. Основними пріоритетами фрункціонування органів управління $\epsilon$ задоволення потреб споживачів, надання їм якісних і своєчасних послуг, формування довіри громадян до уряду. Перспективними напрямами вдосконалення публічного управління в забезпеченні сталого розвитку мають бути: фрормування гнучкої, стабільної та ефективно системи управління; профресіоналізація державної служби; упровадження принципів децентралізації системи державного управління, сервісного адміністрування, корпоративізму і неокорпоративізму, менеджеризму тощо. Упровадження есрективних механізмів реформування публічного управління сприятиме успішному виконанню стратегічних завдань розвитку України.

Ключові слова: публічне управління, ресормування, вдосконалення публічного управління, сталий розвиток
Formulation of the problem in general. Internal and external phenomena, European integration and globalization processes affect all spheres of public life, including public administration in Ukraine. The national system of state power is characterized by rather complex and contradictory processes aimed at a radical reform of the cumbersome and inefficient system of public administration. The system needs radical modernization that would enable a reliable and efficient modern system of public administration.

Low level of efficiency of management of socio-economic processes, poor quality of administrative services, inefficient use of taxpayers' funds, low level of public trust in public authorities are the factors that determine the need for improvement of public administration in Ukraine in general and public administration in particular. At the same time, it is advisable to use the experience of reforming public administration in other countries, which will allow both to explore the best world practices in this field and to determine the prospects for their further adaptation to domestic conditions. This will help to avoid some of the negative effects of the reorganization of the Ukrainian governance system in ensuring sustainable development. 
Analysis of recent research and publications. The issues of functioning of the public administration system and possible directions of its improvement are considered in the works of many domestic and foreign researchers, in particular the following: V. Bashtannik, Y. Vatulia, O. Golubutsky, B. Jenkins, R. Kearney, Y. Kuznetsova, M. Spicer and others. However, consideration of current areas for improving public administration for sustainable development needs to be properly addressed.

Unresolved parts of the common problem. Despite the considerable contribution of these scientists to the development of this problem, the specifics and priority areas for improving public administration for sustainable development are still poorly understood and need separate consideration.

The purpose of the article - to analyze the experience of reforming the sphere of public administration, to outline the prospects of improving public administration in ensuring sustainable development.

Presenting main material. The structure of the transformation of systems and mechanisms of power takes place in the current conditions of increasing globalization processes. As a consequence, the shortcomings of the traditional administrative-bureaucratic concept of state and public administration are revealed. This leads to the search for new alternative forms of management, adapted to the current state of the world.

The process of public administration reform is presented as a transition from traditional values to new, effective management systems that can easily adapt to an ever-changing external environment. As a result of administrative reform comes the principle of autonomy of responsibility for the execution of the main mission assigned to state structures. Therefore, organizational flexibility, innovation management, decentralization, staff freedom of action should be addressed in the foreground.

Today it is possible to distinguish the main spheres within which the reform of public administration is carried out at the present stage in ensuring sustainable development:

1) system of relations of executive bodies with other state institutes of management (horizontally and vertically);

2) organizational structures, coordination and control mechanisms, including central administration, regional and local government;

3) management systems and methods, administrative procedures and processes;

4) personnel policy and public service;

5) management of public finances and budget execution of agencies [1].
Cabinet of Ministers of Ukraine Appointment No. 1102-p of December 18, 2018 approved a new version of the Strategy of reforming the public administration of Ukraine for the period up to 2021 and a plan of measures for its implementation for 2019-2021, approved by the Decree of the Cabinet of Ministers of Ukraine dated June 24, 2016 No. 474 .

The Strategic Developer has announced its 2018 update results for SIGMA Expert Programs. The Committee on Management and Audit Complex conducted the management of the Accounting Chamber of Ukraine and reported consultations with prominent parties. The purpose of the Public Administration Reform Strategy is to improve the public administration system and thus to increase the country's competitiveness. The implementation of this Strategy should result in a more efficient and accountable public administration that works in the public interest, ensures the country's sustainable development and provides quality services.

An indicator of the effectiveness of public administration systems is the position of the state in relevant international rankings. According to the Global Competitiveness Index (for 2018), Ukraine ranks 110th (out of 140 countries) in the category of "state institutions", 49th in the category of "budget transparency", 82nd place in the category of "burden of state regulation". In the World Bank's Doing Business ranking, Ukraine's rankings are the best - in the overall ranking in 2018, Ukraine ranks 71st, and in the field of business opening, Ukraine has risen from 70th place in 2015 to 56th place in 2018. Improving Ukraine's position will testify to the successful implementation of this Strategy [5].

Strategy based on the principle of public administration reform defines the following areas:

1) formation and coordination of public policy (strategic planning of public policy, quality of regulatory framework);

2) modernization of the civil service and human resources management;

3) ensuring accountability of public authorities;

4) provision of administrative services;

5) public finance management.

The effectiveness of public administration depends directly on the activities of senior executives, whose underestimation of their work always leads to negative consequences. Transformational processes in modern society require the employee to possess such traits as the ability to make decisions quickly, adapt flexibly to changing situations and production technologies, creativity, ability to innovate. In the future, this could lead to the creation of a separate insti- 
tute - the service of senior officials, which allows to select the most talented and competent specialists, focused not on their own careers, but on honest performance of their duties [2]. For the same purpose, standards of professional competence of senior officials in the field of management are introduced, which in modern conditions requires not only knowledge but also new qualities of state leaders. It is about their ability to set strategic goals and priorities, understand the political context and institutional factors that determine a particular situation; take into account the position and interests of different groups and adjust the balance of forces in the right direction; evaluate the ethical and social implications of decisions; to ensure adherence to democratic norms and values, to manage political and organizational changes taking into account cultural, national, institutional factors [3].

Service administration is a new understanding of public authorities as structures that provide services to citizens, which envisages: the opening of specialized support services for the public, providing consultancy services on public services; creation of an electronic system of providing services, which consists in placing on the official site of the ministries the rules, requirements, the order of provision of relevant services, the required electronic forms and other accompanying documents; establishment of a quality control service at each ministry, whose mandate is: population survey, constant monitoring of the level of satisfaction of the population with the services provided, development and improvement of the system of indicators of quality of service evaluation, audit and development of recommendations for reporting agencies [4].

Decentralization - the ability to make pralines at grassroots level - where problems arise. In this case, territorial decentralization means the transfer of powers from the center to the regional and local level, from central bodies - to their territorial missions. It is also possible to delegate authority within one organization from upper to lower levels of government. In general, functional decentralization is aimed at the creation of specialized semi-autonomous state agencies, which assume most of the service functions and operate on the basis of agreements with central agencies [2].

The peculiarities of public administration in Ukraine and the challenges that confront it give us grounds to suggest ways of improving the public administration system in ensuring sustainable development in our country through the implementation of reform, namely:

1. Ensuring social efficiency, social performance and social justice. Building a real social state capable of realizing citizens' declared rights to a decent life should be the main goal of improving public administration. The new system of public administration must meet the criteria of social efficiency and effectiveness. Modernization should be oriented to the realization of social values, to the achievement of social effects, capable of making each person's life more dignified, free, and the relations between people more equitable and equal.

2. Maintaining a balance of interests and a civil dialogue between different social groups and socio-cultural groups. This trend is related to the task of ensuring social efficiency. In fulfilling this mission, the state should act as an arbiter between different social groups, reducing the severity of social conflicts between them, creating conditions for the development of social mechanisms of self-organization and social order through the selection and articulation of common interests and social aspirations. Not only does social schism cause instability in society, but it also blocks the action of motivational mechanisms, which becomes a major obstacle to mobilizing potential opportunities contained in social capital.

3. Reducing the scope and resources of public administration. The problems of reducing the costs of financing the public administration system remain urgent.

4. Multi-vector democratization of the public sector. The most important condition for effective work of public authorities is publicity, publicity and obligation to justify the decisions taken, to ensure the exercise of the right of citizens to clarify them, to increase the responsibility for punishment for providing erroneous or misleading information, as well as to expand advisory and information-analytical work. public organizations and the population.

5. Improving the quality of services and the mechanism of their control. Attempts by the heads of various institutes to place in the center of activity of the state the service of interests and satisfaction of the needs of citizens. Meanwhile, these attempts are met with strong resistance at the local level, which intensifies the problem of involving the public in the evaluation process.

6. Ensuring strategic orientation of all management processes. An important part in the formation and strengthening of the Ukrainian statehood should be played by the programmatic and strategic component, which should unite the joint activity of all public administration entities in Ukraine.

7. Introduction of new information technologies. While a few years ago the problem of saturation of public authorities in information and computer technology was being solved, today the 
focus is on increasing the return on investment in information technologies associated with the process of improving the organizational structures and work of the authorities. The widespread use of modern information and telecommunication technologies based on the formation of national networks uniting the local networks of regions, ministries, the use of international standards for the use of information technologies - should become an important area of public administration reform in Ukraine.

8. Introduction of new social technologies in management activities. In modern scientific practice, when considering the role of social technologies in management activity, the focus is on the further development of special, well-thought out and clearly spelled out operations and actions that are able to optimize the relations between different actors involved in the management process (including the public) $[6 ; 7]$.

Thus, it can be stated that innovative social technologies of improvement of public management are a mechanism for combining experience and knowledge with the conditions of their implementation in modern management practice.

Conclusions. Thus, based on the analysis of the latest approaches to the implementation of state-administrative reforms, we conclude that the main priorities of the functioning of government bodies are meeting the needs of consumers, providing them with quality and timely services, building public confidence in the government. Promising areas for improving public governance in sustainable development should be: developing a flexible, stable and efficient management system; professionalization of the civil service; implementation of principles of decentralization of the system of public administration, service administration, corporatism and neo-corporatism, managerialism, which will help to increase the productivity of work of state institutions, bringing the state closer to the citizens. The introduction of effective mechanisms for reforming public administration will contribute to the successful fulfillment of Ukraine's strategic development goals. The results of the study will be useful for further theoretical developments on the theory of public governance in general, which may be important for effective governance by national public authorities and the adaptation of national public administration to European and world standards.

\section{REFERENCES:}

1. Адміністративна ресрорма в Україні: сучасний стан, проблеми та перспективи : кол. моногр. I В.М. Алексєєв та ін. ; заг. ред. Н.Р. Нижник, Н.Т. Гончарук; Секретаріат Кабінету Міністрів України. Дніпро : Вид-во «Монолит», 2009. 384 с.

2. Баштанник В.В. Трансфрормація державного управління в контексті європейських інтеграційних процесів : монографрія / Нац. акад. держ. упр. при Президентові України, Дніпропетр. регіон. ін-т держ. упр. Дніпро : ДРІДУ НАДУ, 2010. 389 с.

3. Кузнецова Ю.А. Повышение качества и эфрфективности бюджетных услуг: обобщение опыта зарубежных стран. URL : http://www.anrb.ru/isei/ cf2006/d897.htm.

4. Ватуля Ю. Сучасні теорії та моделі державного управління у західній науці і практиці та Україна. URL : www.nbuv.gov.ua/portal/Soc_Gum/ Apdup/2010_1/2_90-99.pdf

5. Державна служба України в цифррах. URL : http://nads.gov.ua/ control/uk/index.

6. Kearney R. C. Reinventing Government. The New Public Management and Civil Service-Systems in International Perspective. The Danger of Throwing the Baby out with the Bathwater. Review of Public Personnel Administration. 2008. Vol. XVIII. № 4.

7. Spicer M. Public Administration, the History of Ideas, and the Reinventing Government Movement. Public Administration Review. 2003. Vol. 64. № 3. 